УДК 37.013

\title{
МОТИВАЦИОННЫЕ АСПЕКТЫ ПРОБЛЕМАТИКИ ВОВЛЕЧЕНИЯ СТУДЕНТОВ В НАУЧНУЮ ДЕЯТЕЛЬНОСТЬ В УСЛОВИЯХ СОВРЕМЕННЫХ РЕАЛИЙ. СИНОПСИС ИССЛЕДОВАНИЯ
}

\author{
Викторов Александр Геннадьевич \\ действительный член \\ «Международного комитета по интеллектуальному \\ сотрудничеству - Лиги интеллектуалов», \\ советник Российской Академии Естествознания (РАЕ), \\ преподаватель
}

ГАПОУ АО «Астраханский колледж арт-фэшн индустрии»

Яркина Татьяна Владимировна

бакалавр, преподаватель

ГАПОУ АО «Астраханский колледж арт-фэшн индустрии»

Аннотация: В статье делается попытка выявить и проанализировать основные направления позволяющие повысить заинтересованность студентов и педагогов в ходе развития и интеграции студентов в современную информационную научную среду.

В ходе проведения исследования были выявлены направления нуждающиеся во всестороннем стимулировании, что в свою очередь, позволит добиться качественных результатов при модернизации современного научного знания и выявления концептуально новых направлений и векторов развития современной отечественной фундаментальной и прикладной науки.

При подготовке данной работы активно использовались методы как, общенаучного знания (анализ, синтез, индукция, дедукция), так и ряд частнонаучных методов и подходов (принципы объективности, системности, историзма, синергетический подход).

Ключевые слова: наука, векторы, стимулирования, инновационная деятельность, векторы, направления, динамика. 


\title{
MOTIVATIONAL ASPECTS OF THE PROBLEM OF STUDENTS ' INVOLVEMENT IN SCIENTIFIC ACTIVITY IN THE CONDITIONS OF MODERN REALITIES. SYNOPSIS OF THE STUDY
}

\author{
Viktorov Alexander Gennadievich \\ honoris causa, full member of the \\ "International Committee on Intellectual Cooperation - \\ League of Intellectuals " International \\ Committee on Intellectual cooperation (ICIC), \\ Advisor to the Russian Academy of Natural Sciences (RAE), \\ teacher \\ GAPOU JSC "Astrakhan College of Art-Fashion Industry» \\ Yarkina Tatyana Vladimirovna \\ bachelor, teacher \\ GAPOU JSC "Astrakhan College of Art-Fashion Industry»
}

\begin{abstract}
The article attempts to identify and analyze the main directions that can increase the interest of students and teachers in the development and integration of students in the modern information and scientific environmentIn the course of the research, the directions that need comprehensive stimulation were identified, which in turn will allow achieving high-quality results in the modernization of modern scientific knowledge and identifying conceptually new directions and vectors of development of modern domestic fundamental and applied science.

In the preparation of this work, methods of both general scientific knowledge (analysis, synthesis, induction, deduction) and a number of private scientific methods and approaches (principles of objectivity, consistency, historicism, synergetic approach) were actively used.
\end{abstract}

Key words: science, vectors, incentives, innovation, vectors, directions. dynamics.

Современные реалии диктуют весьма противоречивое отношение к интеграции в научную деятельность молодых специалистов из числа студентов. [1, 102]

С одной стороны, современной науке требуется грамотное качественное переосмысление некоторых устаревших постулатов, догм теорий и гипотез, с 
другой стороны, постоянное переосмысление молодыми специалистами уже накопленного каталогизированного и систематизированного багажа научных знаний может привести к формированию деструктивных тенденций и вызвать у студентов элементы эклектики [2], что, на наш взгляд, не допустимо в условиях современных реалий.

Однако, при кажущемся достижении определённого апогея динамики развития современных инновационных процессов, наблюдается наличие существенной потребности в развитии и стимулировании определённых областей, как фундаментального, так и прикладного характера, при этом современным педагогам-наставникам не стоит забывать при выборе вектора маршрутизации студентов и постепенной их интеграции в современную научную среду, о важности создания и укрепления логических и причинноследственных связей между уже накопленными и систематизированными научными знаниями и теми постулатами и тенденциями, на которые направлена деятельность будущих молодых специалистов, с целью качественной доработки и переосмысления накопленного ранее опыта, с позиции современного научного знания, при анализа проблематики выбранной ими направленности. [4, 100]

Таким образом, вовлечение студентов в современную качественную и всесторонне развивающую научную работу может быть достигнуто путем снижение рисков получения отрицательного результата, что, в свою очередь, позволит нивелировать психологические барьеры, возникающие у студентов при выборе проблематики для более углублённой интеграции с последующим всесторонним изучением ключевых аспектов данной направленности. [6. 264]

Это может быть достигнуто путем маршрутизации и, своеобразного, патроната, в котором целью является не достижение сиюминутных результатов, а грамотное и адекватное динамичное стимулирование с последующим развитие векторов долгосрочной перспективы. $[8,136]$

Таким образом, будут созданы качественные новые условия, в которых одинаково будут заинтересованы, как молодые специалисты, так и более маститые педагоги-наставники.

Для студентов активное участие в научных мероприятиях станет определённым форматов апробации их практических знаний и позволит стимулировать развитие ряда навыков, которые позволят им, в дальнейшем, существенно повысить вероятность положительных резинатов дальней 
самостоятельной деятельности, в рамках лона современной отечественной науки. $[9,270]$

Для опытных педагогов данная деятельность, так же позволит добиться положительной динамики в ряде аспектов, которые, в наши дни, отличают современного опытного профессионала научной деятельности от своеобразных любителей с устаревшими и весьма архаичными подходами к интеграции молодых специалистов в современную реальную научную и образовательную среду. [10,357]

Не менее важным, в данном случае, выступит формат взаимопомощи, который позволит вышеуказанным специалистам качественно повысить свои наукометрические показатели, которые, в современном обществе, являются косвенным мерилом успехов ученого и определения его научнопедагогического уровня. [3]

Подводя итоги, можно сделать вывод о важности создания качественных условий для интеграции молодых специалистов из числа студентов в научную деятельность с целью создания и продвижения качественного научного знания и добиться преемственности в смене поколений, а так же добиться форматирования научных напылении и школ, диктующих новые концептуальные постулаты и догмы новой формирующейся научной парадигмы.

\section{Список литературы}

1. Цветкова Р.И. Мотивационная сфера личности: Монография [Текст] / Р.И.Цветкова. — Хабаровск: Изд-во ХГПУ, 2000 - с. 102

2. Баум С.М. Шесть сигм в России [Электронный ресурс]. - Сбор данных. - Режим доступа: http://www.six-sigma.ru/index.php?id=266

3. Парамонов А.Г. Инновационная деятельность по привлечению студентов к научной работе. // Молодежь и наука: реальность и будущее: Материалы II Международной научно-практической конференции (г. Невинномысск, 3 марта 2009): в 9 томах / Том 1: Педагогика. Невинномысск: НИЭУП, 2009.

4. Миронов В.А., Майкова Э.Ю. Социальные аспекты активизации научно исследовательской деятельности студентов вузов: Монография. Тверь: ТГТУ, 2004. с. 100

5. Асеев В.Г. Мотивация поведения и формирования личности. М.: Мысль. 2002. с. 344

6. Ильин Е.П. Мотивация и мотивы. СПб: Питер. 2005. с. 264 
7. Константиновский Д.Л., Вознесенская Е.Д., Чередниченко Г.А., Хохлушкина Ф.А. Образовательные и жизненные траектории молодёжи. М.: ЦСПиМ. 2011. с. 296

8. Рудик П.А. Мотивы поведения деятельности. М.: Наука. 2003. с. 136

9. Узнадзе Д.Н. Психологические исследования. М.: Наука. 2003. с. 270

10. Шульц Д., Шульц С. Психология и работа. СПб: Питер. 2003. с. 357

(C) А.Г. Викторов, Т.В. Яркина, 2021 